\title{
Solar Thermochemical Hydrogen Production via Terbium Oxide Based Redox Reactions
}

\author{
Rahul Bhosale, Anand Kumar, and Fares AlMomani \\ Department of Chemical Engineering, College of Engineering, Qatar University, P.O. Box 2713, Doha, Qatar \\ Correspondence should be addressed to Rahul Bhosale; rahul.bhosale@qu.edu.qa
}

Received 24 November 2015; Revised 16 December 2015; Accepted 5 January 2016

Academic Editor: Juan M. Coronado

Copyright (C) 2016 Rahul Bhosale et al. This is an open access article distributed under the Creative Commons Attribution License, which permits unrestricted use, distribution, and reproduction in any medium, provided the original work is properly cited.

The computational thermodynamic modeling of the terbium oxide based two-step solar thermochemical water splitting (Tb-WS) cycle is reported. The 1st step of the Tb-WS cycle involves thermal reduction of $\mathrm{TbO}_{2}$ into $\mathrm{Tb}$ and $\mathrm{O}_{2}$, whereas the 2nd step corresponds to the production of $\mathrm{H}_{2}$ through $\mathrm{Tb}$ oxidation by water splitting reaction. Equilibrium compositions associated with the thermal reduction and water splitting steps were determined via HSC simulations. Influence of oxygen partial pressure in the inert gas on thermal reduction of $\mathrm{TbO}_{2}$ and effect of water splitting temperature $\left(T_{L}\right)$ on Gibbs free energy related to the $\mathrm{H}_{2}$ production step were examined in detail. The cycle $\left(\eta_{\text {cycle }}\right)$ and solar-to-fuel energy conversion $\left(\eta_{\text {solar-to-fuel }}\right)$ efficiency of the Tb-WS cycle were determined by performing the second-law thermodynamic analysis. Results obtained indicate that $\eta_{\text {cycle }}$ and $\eta_{\text {solar-to-fuel }}$ increase with the decrease in oxygen partial pressure in the inert flushing gas and thermal reduction temperature $\left(T_{H}\right)$. It was also realized that the recuperation of the heat released by the water splitting reactor and quench unit further enhances the solar reactor efficiency. At $T_{H}=2280 \mathrm{~K}$, by applying $60 \%$ heat recuperation, maximum $\eta_{\text {cycle }}$ of $39.0 \%$ and $\eta_{\text {solar-to-fuel }}$ of $47.1 \%$ for the Tb-WS cycle can be attained.

\section{Introduction}

$\mathrm{H}_{2}$ is considered as one of the most promising future energy sources as it is characterized by a very high energy density $(143 \mathrm{MJ} / \mathrm{kg})$ and environmentally clean utilization. $\mathrm{H}_{2}$ can be produced by gasification and reforming of fossil fuels [1-3], pyrolysis and reforming of biomass [4-7], ethanol and methanol decomposition [8-11], and so forth. Literature survey indicates that, in recent years, the researchers are attracted more towards production of $\mathrm{H}_{2}$ from water by using solar energy as the heat source.

Solar radiation is an essentially inexhaustible energy source that delivers about $100,000 \mathrm{TW}$ to the earth. Harvesting the solar radiation and converting it effectively into renewable $\mathrm{H}_{2}$ fuel from $\mathrm{H}_{2} \mathrm{O}$ provide a promising path for a future sustainable energy economy. Solar $\mathrm{H}_{2}$ production via metal oxide $(\mathrm{MO})$ based thermochemical $\mathrm{H}_{2} \mathrm{O}$ splitting reaction is considered as one of the capable new technologies for fulfillment of future energy requirement. In comparison to the high temperature direct thermolysis of $\mathrm{H}_{2} \mathrm{O}$, the $\mathrm{MO}$ based thermochemical cycle is advantageous as (a) this cycle needs lower temperatures as compared to thermolysis, (b) it has no explosive mixture formation as the production of $\mathrm{H}_{2}$ and $\mathrm{O}_{2}$ can be carried out in two different steps, and (c) it is environmentally and thermodynamically more feasible compared to thermolysis.

Production of solar $\mathrm{H}_{2}$ via $\mathrm{MO}$ based thermochemical reactions is a two-step process. In the first step, the MO is reduced into a lower valence MO or metal with the help of solar energy. The reduced MO is further reoxidized in the second step via $\mathrm{H}_{2} \mathrm{O}$ splitting reaction. Several $\mathrm{MO}$ based redox systems were theoretically and experimentally studied towards thermochemical water splitting reaction which includes $\mathrm{ZnO} / \mathrm{Zn}$ cycle [12-15], $\mathrm{Fe}_{3} \mathrm{O}_{4} / \mathrm{FeO}$ cycle [1620], $\mathrm{SnO}_{2} / \mathrm{SnO}$ cycle [21-23], ferrite cycle [24-30], ceria cycle [31-36], and perovskite cycle [37-41]. Previous investigations indicate that these cycles are promising towards solar water splitting reaction but possess certain imitations also. The $\mathrm{ZnO} / \mathrm{Zn}$ and $\mathrm{SnO}_{2} / \mathrm{SnO}$ cycles are volatile in nature and hence material loss during multiple cycles is inevitable. On the other hand, $\mathrm{Fe}_{3} \mathrm{O}_{4} / \mathrm{FeO}$, ferrite, ceria, and perovskite cycles depend upon the nonstoichiometry of the redox 
materials and hence the complete reduction and oxidation were not observed which resulted in the fact that smaller amounts of $\mathrm{H}_{2}$ production were observed. Due to these reasons, investigations are underway to explore new thermochemical cycles for the production of $\mathrm{H}_{2}$ via water splitting reaction.

In this study, computational thermodynamic modeling of a new terbium oxide based two-step solar thermochemical water splitting (Tb-WS) cycle was performed to determine its thermodynamic efficiency by using HSC Chemistry software and databases (HSC 7.1). Thermodynamic equilibrium composition of the solar thermal reduction of terbium oxide (step 1) and water splitting reaction (step 2) were determined. Effect of oxygen partial pressure in the inert flushing gas used inside the solar reactor during thermal reduction step on thermodynamic efficiency of the process was explored in detail. Furthermore, the effect of water splitting temperature $\left(T_{L}\right)$ on Gibbs free energy associated with the oxidation of $\mathrm{Tb}$ (via water splitting reaction) was also explored. In addition to the thermodynamic equilibrium analysis, the solar reactor thermodynamic modeling was also carried out. Absorption efficiency of the solar reactor, solar energy input required to run the Tb-WS cycle, heat losses due to radiation, rate of heat rejected by the quench unit and water splitting reactor, Tb-WS cycle efficiency, and solar-to-fuel energy conversion efficiency were estimated. Typical redox reactions involved in the $\mathrm{Tb}$-WS cycle are presented in Figure 1.

The redox reactions involved in the Tb-WS cycle are as follows:

$$
\begin{array}{r}
\mathrm{TbO}_{2} \longrightarrow \mathrm{Tb}(\mathrm{g})+\mathrm{O}_{2}(\mathrm{~g}) \\
\mathrm{Tb}+2 \mathrm{H}_{2} \mathrm{O}(\mathrm{g}) \longrightarrow \mathrm{TbO}_{2}+2 \mathrm{H}_{2}(\mathrm{~g})
\end{array}
$$

Thermodynamic data associated with $\mathrm{TbO}_{2}, \mathrm{~Tb}, \mathrm{O}_{2}, \mathrm{H}_{2} \mathrm{O}$, and $\mathrm{H}_{2}$ as the reactive species were taken from HSC and the analysis was performed by assuming continuous operation of the solar reactor with inlet molar flow rate of $\mathrm{TbO}_{2}$ equal to $1 \mathrm{~mol} / \mathrm{sec}$. The boiling and fusion points for $\mathrm{Tb}$ are 1629 and $3396 \mathrm{~K}$, respectively. Similar to other lanthanides, Tb possesses low toxicity. According to Patnaik [42], the crust global abundance of $\mathrm{Tb}$ is estimated to be $1.2 \mathrm{mg} / \mathrm{kg}$.

\section{Equilibrium Thermodynamic Analysis}

Previous investigations associated with the production of solar fuels via MO based thermochemical reactions indicate that the heat energy that is thermal reduction temperature $\left(T_{H}\right)$ required to achieve complete reduction of MOs can be decreased if ultra-high purity inert flushing gas with lower oxygen partial pressures in the range of $10^{-3}$ to $10^{-8}$ atm is used during the reduction step inside the solar reactor $[43,44]$. The effect of oxygen partial pressure in the inert flushing gas on thermal reduction of $\mathrm{TbO}_{2}$ was examined in this study and the results are reported in Figure 2. The reported findings indicate that, similar to the previous $\mathrm{MO}$ cycles, $T_{H}$ required for the thermal reduction of $\mathrm{TbO}_{2}$ can be lowered due to the drop in the oxygen partial pressure in the inert flushing gas. For example, at oxygen partial pressure of

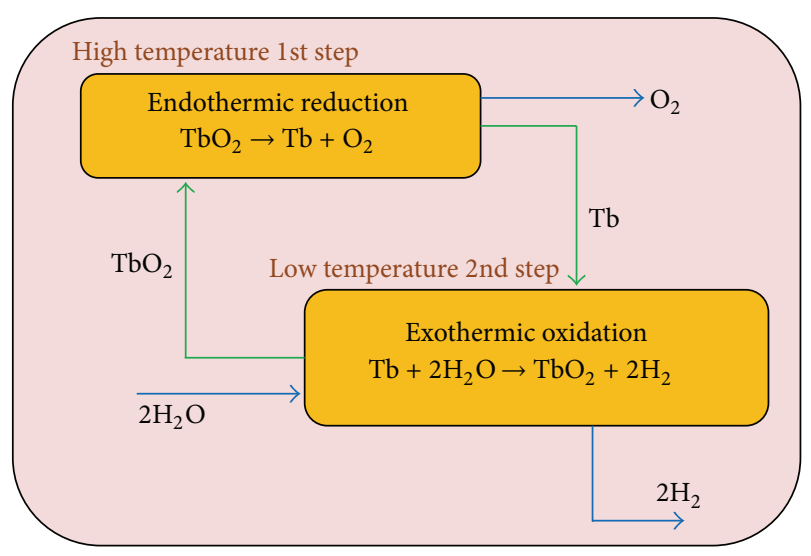

Figure 1: Typical redox reactions involved in the Tb-WS cycle.

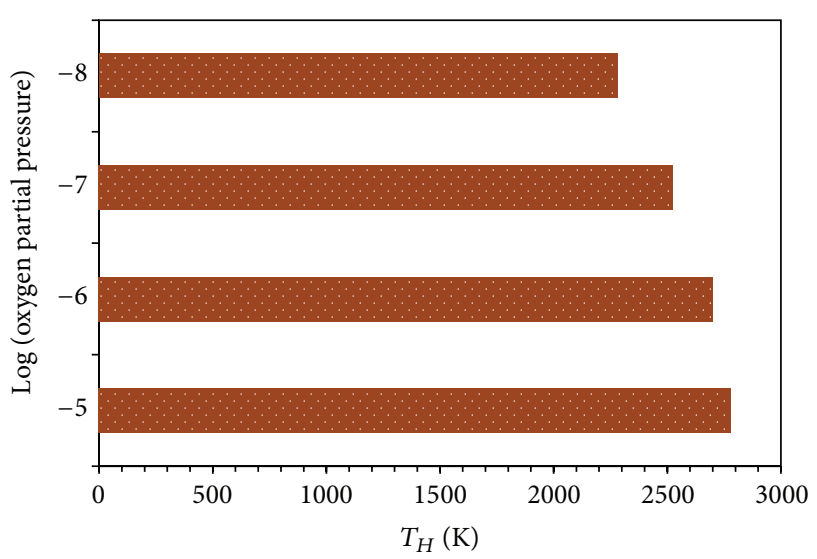

FIGURE 2: Influence of oxygen partial pressure in the inert flushing gas on $T_{H}$ for Tb-WS cycle.

$10^{-5}$ atm, $T_{H}$ required for the complete dissociation of $\mathrm{TbO}_{2}$ is equal to $2780 \mathrm{~K} . T_{H}$ can be decreased by 80,260 , and $500 \mathrm{~K}$ if the oxygen partial pressure in the inert flushing gas is reduced to $10^{-6}, 10^{-7}$, and $10^{-8}$ atm, respectively.

In addition to $T_{H}$, the effect of oxygen partial pressure in the inert flushing gas on equilibrium compositions associated with the thermal reduction of $\mathrm{TbO}_{2}$ was also investigated. HSC simulations reported in Figure 3 indicate that the slope of the decrease in the equilibrium concentration of $\mathrm{TbO}_{2}$ and increase in the equilibrium concentration of $\mathrm{Tb}(\mathrm{g})$ is shifted significantly towards the lower $T_{H}$ due to the decrease in the oxygen partial pressure in the inert flushing gas. The possible reason behind this shift is the reduction in the entropy of the product gases due to the drop in the oxygen partial pressure in the inert flushing gas used inside the solar reactor.

As per the HSC simulations, formation of $\mathrm{Tb}_{2} \mathrm{O}_{3}$ is an intermediate step in the thermal reduction of $\mathrm{TbO}_{2}$ into $\mathrm{Tb}(\mathrm{g})$ and $\mathrm{O}_{2}(\mathrm{~g})$. In addition, it was observed that the $\mathrm{Tb}$ formation is achieved only after decomposition of $\mathrm{Tb}_{2} \mathrm{O}_{3}$. Hence, as we are dealing with the final products, there is no need to consider $\mathrm{Tb}_{2} \mathrm{O}_{3}$ in the thermodynamic analysis. Therefore, $\mathrm{Tb}_{2} \mathrm{O}_{3}$ is not included in this study. 


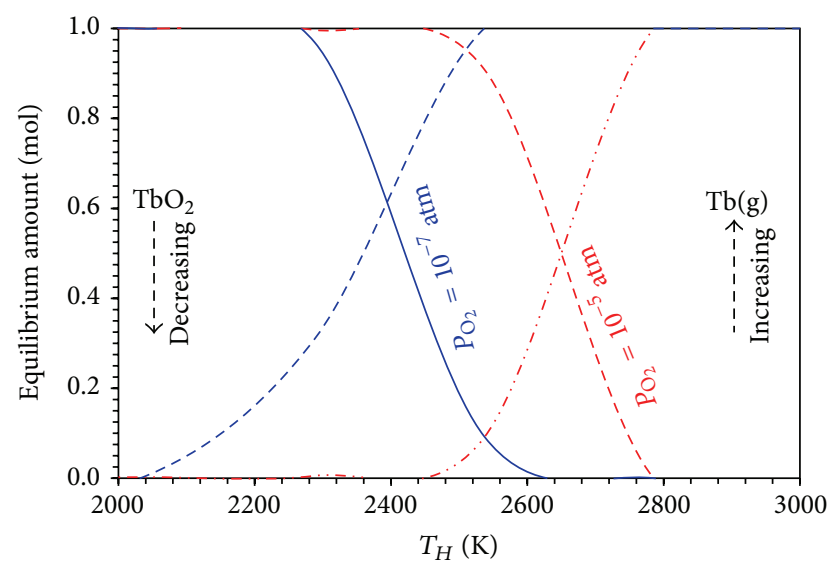

FIGURE 3: Influence of oxygen partial pressure in the inert flushing gas on equilibrium compositions associated with the thermal reduction of $\mathrm{TbO}_{2}$.

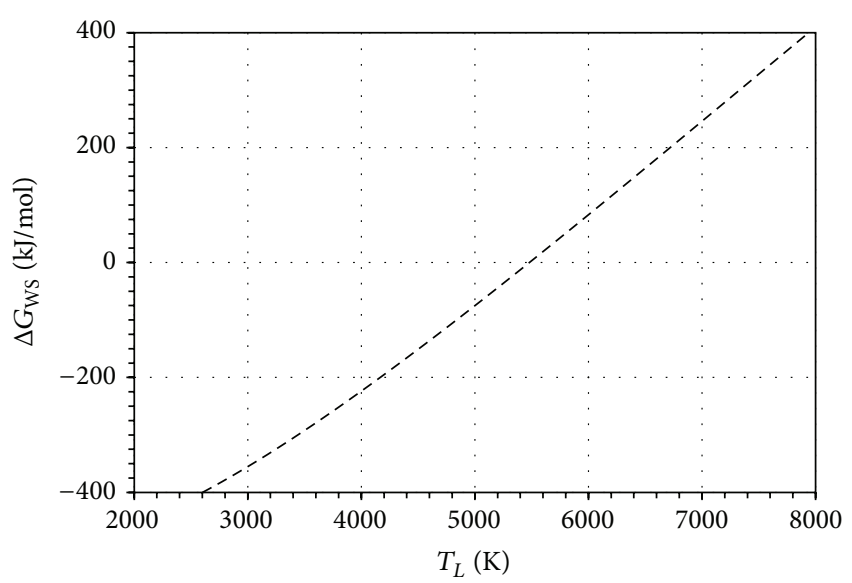

FIGURE 4: Variation in Gibbs free energy as a function of $T_{L}$ for TbWS cycle.

Figure 4 shows the variation in the Gibbs free energy related to the water splitting reaction as a function of $T_{L}$. The Gibbs free energy change plot indicates that the hydrogen production via water splitting reaction and oxidation of $\mathrm{Tb}$ is feasible below $5400 \mathrm{~K}$ (pressure $=1 \mathrm{~atm}$ ). It was also observed that $\Delta G_{\mathrm{WS}}$ decreases by $434.5 \mathrm{~kJ} / \mathrm{mol}$ due to the drop in $T_{L}$ from 5400 to $300 \mathrm{~K}$.

\section{Tb-WS Solar Reactor Thermodynamic Modeling}

Solar reactor operating the Tb-WS cycle was thermodynamically modeled by using the principles of the second law of thermodynamics. Figure 5 shows the process flow configuration of the Tb-WS cycle which includes a solar reactor, a quench unit, a water splitter, and an ideal $\mathrm{H}_{2} / \mathrm{O}_{2}$ fuel cell. Like the previous studies, for the solar reactor thermodynamic modeling, several assumptions were made such as the following [20]:

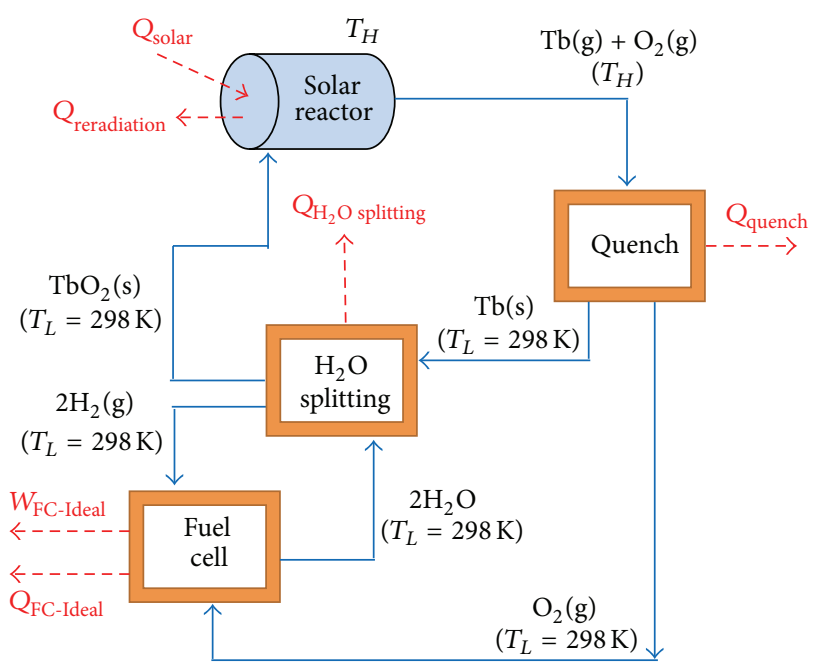

FIGURE 5: Process flow diagram for $\mathrm{H}_{2}$ production via Tb-WS cycle.

(a) The Tb-WS solar reactor considered as a perfectly insulated blackbody absorber with effective emissivity and absorptivity equal to 1 and negligible conductive convective heat losses.

(b) Atmospheric $\mathrm{H}_{2}$ production and steady state conditions with negligible viscous losses and kinetics/potential energies.

(c) Complete conversion of all the reactions associated with the Tb-WS cycle.

(d) Products separating naturally without laying out any work.

(e) Omission of heat exchanger required for recovering the sensible latent heat from the thermodynamic modeling.

Previously reported methodology was employed to perform the solar reactor modeling [20]. HSC Chemistry software and databases were used to get the thermodynamic properties of the reactive species and the calculations are normalized to the $\mathrm{TbO}_{2}$ molar flow rate $(1 \mathrm{~mol} / \mathrm{sec})$ entering the solar reactor.

The solar reactor absorption efficiency $\left(\eta_{\text {absorption }}\right)$, which is defined as the net rate at which energy is being absorbed by the solar reactor divided by the solar energy input through the aperture, can be calculated as per

$$
\eta_{\text {absorption }}=1-\left(\frac{\sigma T_{H}^{4}}{I C}\right),
$$

where $I$ is direct-normal solar irradiance (normal bean insolation) $\left(\mathrm{W} / \mathrm{m}^{2}\right), C$ is solar flux concentration ratio (ratio of the solar flux intensity achieved after concentration to the normal beam insolation, dimensionless number) (suns), $T_{H}$ is solar reactor temperature required for the thermal reduction of $\mathrm{TbO}_{2}(\mathrm{~K})$, and $\sigma$ is Stefan-Boltzmann constant which is equal to $5.6705 \times 10^{-8}\left(\mathrm{~W} / \mathrm{m}^{2} \cdot \mathrm{K}^{4}\right)$.

Figure 6 indicates a significant improvement in $\eta_{\text {absorption }}$ due to the reduction in $T_{H}$ and oxygen partial pressure in the inert flushing gas used inside the solar reactor decreases. At 


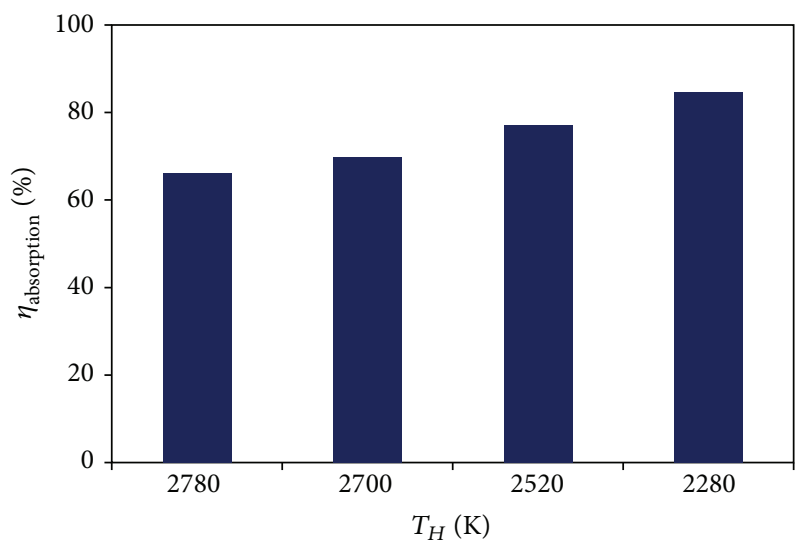

Figure 6: Effect of $T_{H}$ on $\eta_{\text {absorption }}$.

oxygen partial pressure in the inert flushing gas of $10^{-5} \mathrm{~atm}$, the required $T_{H}$ is $2780 \mathrm{~K}$ and corresponding $\eta_{\text {absorption }}$ is $66.1 \%$. As the oxygen partial pressure in the inert flushing gas is further lowered to $10^{-7}$ atm, $T_{H}$ can be decreased to $2520 \mathrm{~K}$ and $\eta_{\text {absorption }}$ can be increased up to $77.1 \%$. As per the conditions employed in this study, the maximum $\eta_{\text {absorption }}$ that can be achieved is equal to $84.7 \%$ (oxygen partial pressure in the inert flushing gas is $10^{-8}$ atm and $T_{H}$ is $2280 \mathrm{~K}$ ).

In addition to the oxygen partial pressure in the inert flushing gas and $T_{H}, C$ also has a significant impact on $\eta_{\text {absorption }}$. At oxygen partial pressure of $10^{-8}$ atm and $T_{H}$ of $2280 \mathrm{~K}$, the lower values of $C$ (2000 suns) yield $\eta_{\text {absorption }}$ of $23.4 \%$. As the value of $C$ increases up to 3000 to 5000 suns, $\eta_{\text {absorption }}$ can get enhanced up to $48.9 \%$ and $69.3 \%$, respectively.

The net energy required to operate the Tb-WS solar reactor can be determined according to the following equations:

$$
\begin{aligned}
Q_{\text {reactor-net }} & =Q_{\mathrm{TbO}_{2} \text {-heating }}+Q_{\mathrm{TbO}_{2} \text {-reduction }} \\
Q_{\mathrm{TbO}_{2} \text {-heating }} & =\left.\dot{n} \Delta H\right|_{\mathrm{TbO}_{2} @ T_{L}} \rightarrow \mathrm{TbO}_{2} @ T_{H} \\
Q_{\mathrm{TbO}_{2} \text {-reduction }} & =\left.\dot{n} \Delta H\right|_{\mathrm{TbO}_{2} @ T_{H}} \rightarrow \mathrm{Tb}+\mathrm{O}_{2}(\mathrm{~g}) @ T_{H}
\end{aligned}
$$

The variation in $Q_{\text {reactor-net }}$ with respect to the change in $T_{H}$ is presented in Figure 7. Presented results indicate that the required $Q_{\text {reactor-net }}$ decreases with the drop in $T_{H}$ and oxygen partial pressure in the inert flushing gas. As $T_{H}$ is reduced from $2780 \mathrm{~K}$ (oxygen partial pressure in the inert flushing gas of $10^{-5}$ atm) to $2280 \mathrm{~K}$ (oxygen partial pressure in the inert flushing gas of $\left.10^{-8} \mathrm{~atm}\right), Q_{\text {reactor-net }}$ is also lowered from $1543.0 \mathrm{~kW}$ to $1499.2 \mathrm{~kW}$, respectively.

By using the calculated $\eta_{\text {absorption }}$ and $Q_{\text {reactor-net }}$, total amount of solar energy required for the operation of the $\mathrm{Tb}$ WS cycle can be estimated as

$$
Q_{\text {solar }}=\frac{Q_{\text {reactor-net }}}{\eta_{\text {absorption }}} .
$$

The decrease in $Q_{\text {solar }}$ as a function of reduction in $T_{H}$ and oxygen partial pressure in the inert flushing gas is shown

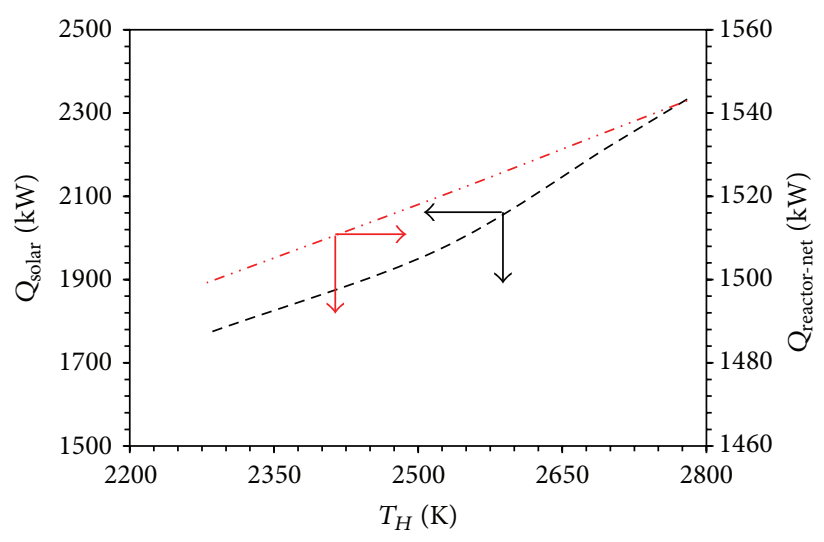

FIGURE 7: Effect of $T_{H}$ on (a) $Q_{\text {solar }}$ and (b) $Q_{\text {reactor-net }}$.

in Figure 7. $2333.2 \mathrm{~kW}$ of solar energy is required for the operation of $\mathrm{Tb}$-WS cycle when the oxygen partial pressure in the inert flushing gas is equal to $10^{-5}$ atm $\left(T_{H}=2780 \mathrm{~K}\right)$. $Q_{\text {solar }}$ is reduced to $1970.3 \mathrm{~kW}$ as the oxygen partial pressure in the inert flushing gas is lowered to $10^{-7}$ atm $\left(T_{H}=2520 \mathrm{~K}\right)$. As per the modeling conditions employed in this study, the minimum $Q_{\text {solar }}(1770.5 \mathrm{~kW})$ is possible at oxygen partial pressure in the inert flushing gas of $10^{-8}$ atm $\left(T_{H}=2280 \mathrm{~K}\right)$. The reason behind this drop in $Q_{\text {solar }}$ is the elevation in $\eta_{\text {absorption }}$ due to the fall in $T_{H}$ from 2780 to $2280 \mathrm{~K}$ as the oxygen partial pressure in the inert flushing gas is reduced from $10^{-5}$ to $10^{-8}$ atm.

Radiation heat losses from the Tb-WS solar reactor are unavoidable as the operating temperatures are very high. These losses can be calculated as

$$
Q_{\text {reradiation }}=Q_{\text {solar }}-Q_{\text {reactor-net }} \text {. }
$$

The radiation heat losses associated with the Tb-WS cycle are presented in Figure 8(a). The plot shown indicates that, at $T_{H}$ $=2780 \mathrm{~K}, 790.2 \mathrm{~kW}$ of heat is lost from the solar reactor due to the reradiation. However, the radiation losses are decreased due to the lowering of $T_{H}$. For instance, at $T_{H}=2280 \mathrm{~K}$, only $271.3 \mathrm{~kW}$ of reradiation losses is reported as per the thermodynamic modeling. This is again due to the fact that $\eta_{\text {absorption }}$ of the Tb-WS solar reactor is higher at lower $T_{H}$.

Solar thermal reduction of $\mathrm{TbO}_{2}$ yields $\mathrm{Tb}(\mathrm{g})$ and $\mathrm{O}_{2}(\mathrm{~g})$. As the operating temperatures are very high, these compounds will try to recombine and reform the $\mathrm{TbO}_{2}$. Therefore, it is highly essential to quench these compounds from $T_{H}$ to $T_{L}$ to avoid any recombination. During quenching, it is assumed that the chemical composition of the products remains unaltered. Due to quenching $\mathrm{Tb}(\mathrm{g})$ is cooled down to solid $\mathrm{Tb}$ and automatically gets separated from $\mathrm{O}_{2}(\mathrm{~g})$. Also, during quenching, latent and sensible heat will be lost to the surroundings from the quench unit which can be estimated as

$$
Q_{\text {quench }}=-\left.\dot{n} \Delta H\right|_{\mathrm{Tb}(\mathrm{g})+\mathrm{O}_{2}(\mathrm{~g}) @ T_{H} \rightarrow \mathrm{Tb}(\mathrm{s})+\mathrm{O}_{2}(\mathrm{~g}) @ T_{L}} .
$$

The data reported in Figure 8(b) indicates that higher amount of heat is lost due to quenching $(571.4 \mathrm{~kW})$ when $T_{H}$ is $2780 \mathrm{~K}$ (oxygen partial pressure in the inert flushing gas is $10^{-5}$ atm). 


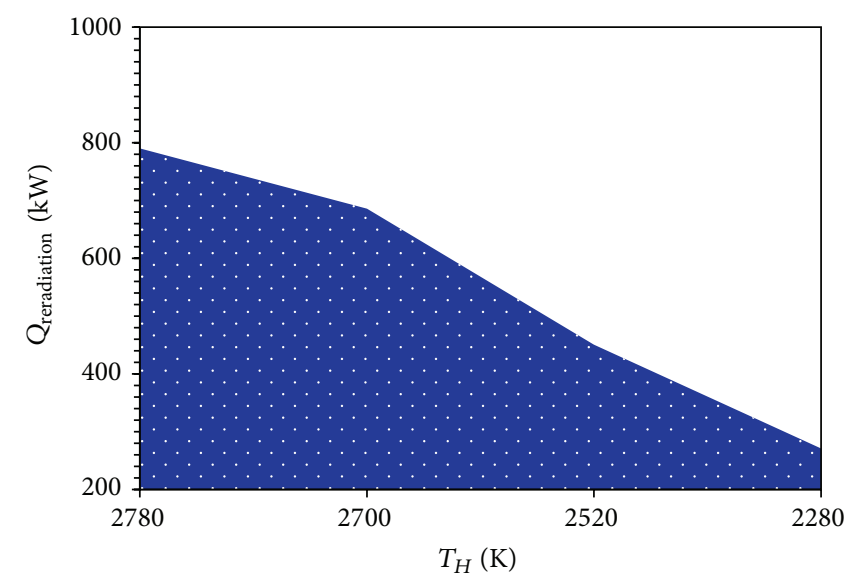

(a)

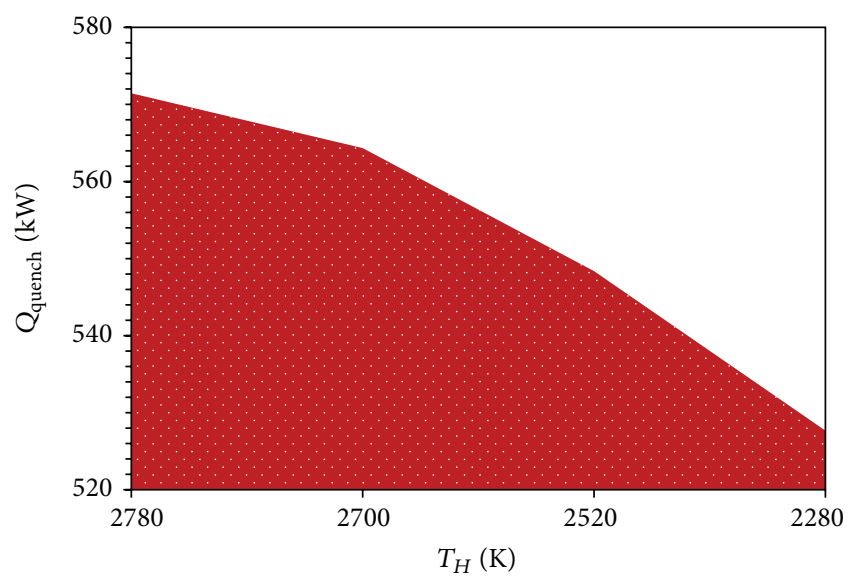

(b)

FIGURE 8: Effect of $T_{H}$ on (a) $Q_{\text {reradiation }}$ and (b) $Q_{\text {quench }}$.

However, as $T_{H}$ is decreased to $2280 \mathrm{~K}$ due to the lowering of oxygen partial pressure in the inert flushing gas $\left(10^{-8} \mathrm{~atm}\right)$, the heat lost is reduced by $43.8 \mathrm{~kW}$.

Because of the irreversible chemical transformations and reradiation losses, the irreversibilities generated in the solar reactor and the quench unit can be determined as

$$
\begin{aligned}
\operatorname{Irr}_{\text {reactor }}= & \left(\frac{-Q_{\text {solar }}}{T_{H}}\right)+\left(\frac{Q_{\text {reradiation }}}{298}\right) \\
& +\left.\dot{n} \Delta S\right|_{\mathrm{TbO}_{2} @ T_{L} \rightarrow \mathrm{Tb}(\mathrm{g})+\mathrm{O}_{2}(\mathrm{~g}) @ T_{H}} \\
\operatorname{Irr}_{\text {quench }}= & \left(\frac{Q_{\text {quench }}}{298}\right) \\
& +\left.\dot{n} \Delta S\right|_{\mathrm{Tb}(\mathrm{g})+\mathrm{O}_{2}(\mathrm{~g}) @ T_{H} \rightarrow \mathrm{Tb}(\mathrm{s})+\mathrm{O}_{2}(\mathrm{~g}) @ T_{L}} .
\end{aligned}
$$

Table 1 lists the $\operatorname{Irr}_{\text {reactor }}$ and $\operatorname{Irr}_{\text {quench }}$ values as a function of $T_{H}$. From the reported numbers, it can be seen that, in case of both the $\mathrm{Tb}$-WS solar reactor and quench unit, $\mathrm{Irr}_{\text {reactor }}$ and $\operatorname{Irr}_{\text {quench }}$ values are maximum at higher $T_{H}$ and decrease with the reduction in $T_{H}$. For instance, $\operatorname{Irr}_{\text {reactor }}$ and $\operatorname{Irr}_{\text {quench }}$ can be lowered by $73.8 \%$ and $7.8 \%$ due to the drop in $T_{H}$ from 2780 to $2280 \mathrm{~K}$.

$\mathrm{H}_{2}$ generation via water splitting reaction can be carried out at $T_{L}$ of $298 \mathrm{~K}$ by transferring the $\mathrm{Tb}$ obtained after the quench unit to the water splitting reactor. The water splitting is an exothermic reaction and hence the rate of heat rejected to the surroundings from the water splitting reactor is estimated as being equal to $399.8 \mathrm{~kW}$ according to

$$
Q_{\mathrm{Tb} \text { oxidation }}=-\left.\dot{n} \Delta H\right|_{\mathrm{Tb}+2 \mathrm{H}_{2} \mathrm{O} \rightarrow \mathrm{TbO}_{2}+2 \mathrm{H}_{2}(\mathrm{~g}) @ T_{L}} \cdot
$$

Similarly, the irreversibility associated with the water splitting reaction is estimated $(1.5 \mathrm{~kW} / \mathrm{K})$ by solving

$$
\begin{aligned}
\operatorname{Irr}_{\text {Sm oxidation }}= & \left(\frac{Q_{\text {Sm oxidation }}}{298}\right) \\
& +\left.\dot{n} \Delta S\right|_{\mathrm{Tb}+2 \mathrm{H}_{2} \mathrm{O} \rightarrow \mathrm{TbO}_{2}+2 \mathrm{H}_{2}(\mathrm{~g}) @ T_{L}} .
\end{aligned}
$$

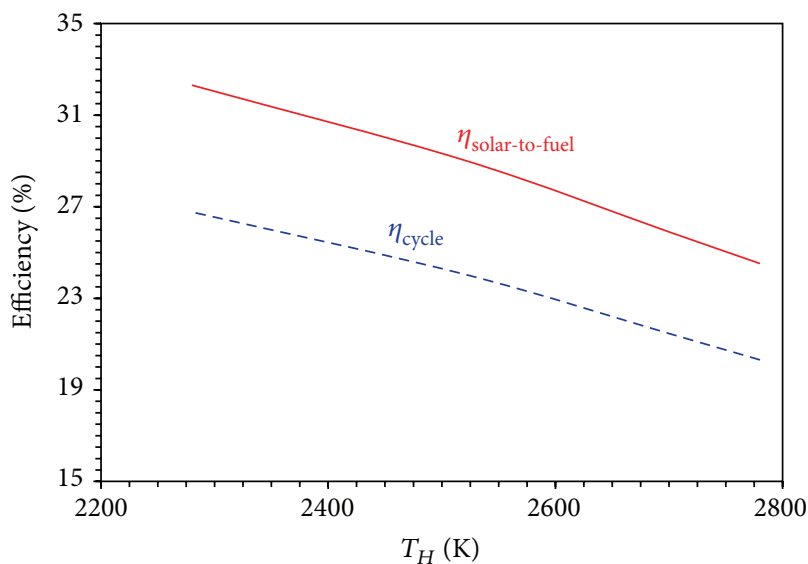

FIGURE 9: $\eta_{\text {cycle }}$ and $\eta_{\text {solar-to-fuel }}$ as a function of $T_{H}$.

To determine the maximum work that can be extracted from the $\mathrm{H}_{2}$ generated, an ideal $\mathrm{H}_{2} / \mathrm{O}_{2}$ fuel cell with $100 \%$ work efficiency is added to the Tb-WS cycle. According to (14) and (15), it was observed that the theoretical work performed and heat energy released by the ideal fuel cell are equal to 473.9 and $97.3 \mathrm{~kW}$ :

$$
\begin{aligned}
& W_{\text {FC-Ideal }}=-\left.\dot{n} \Delta G\right|_{2 \mathrm{H}_{2}(\mathrm{~g})+\mathrm{O}_{2}(\mathrm{~g}) \rightarrow 2 \mathrm{H}_{2} \mathrm{O}(\mathrm{l}) @ 298 \mathrm{~K}} \\
& Q_{\mathrm{FC}-I d e a l}=-\left.(298) \dot{n} \Delta S\right|_{2 \mathrm{H}_{2}(\mathrm{~g})+\mathrm{O}_{2}(\mathrm{~g}) \rightarrow 2 \mathrm{H}_{2} \mathrm{O}(\mathrm{l}) @ 298 \mathrm{~K}} .
\end{aligned}
$$

The cycle $\left(\eta_{\text {cycle }}\right)$ and solar-to-fuel conversion $\left(\eta_{\text {solar-to-fuel }}\right)$ efficiency of the Tb-WS cycle can be defined as

$$
\begin{aligned}
\eta_{\text {cycle }} & =\frac{W_{\text {FC-Ideal }}}{Q_{\text {solar }}} \\
\eta_{\text {solar-to-fuel }} & =\frac{\mathrm{HHV}_{\mathrm{H}_{2}}}{Q_{\text {solar }}} .
\end{aligned}
$$

Variation in $\eta_{\text {cycle }}$ and $\eta_{\text {solar-to-fuel }}$ of the Tb-WS cycle as a function of $T_{H}$ is presented in Figure 9. The data reported 


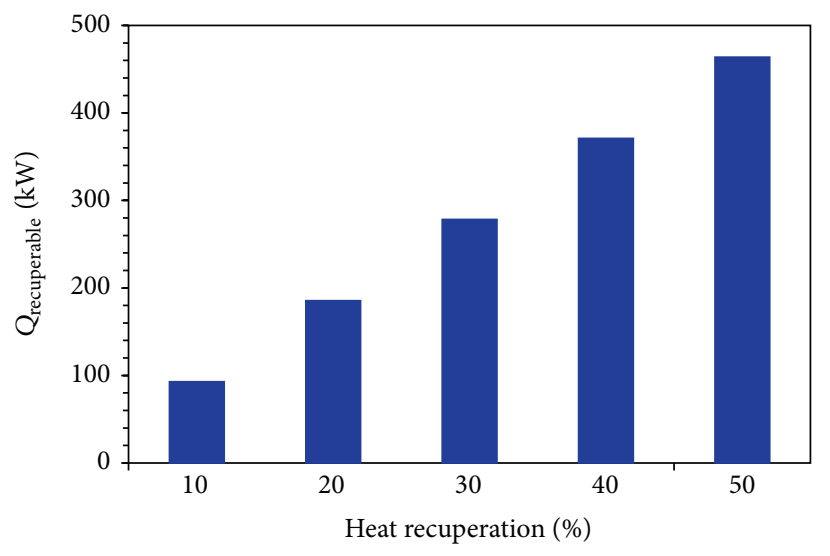

(a)

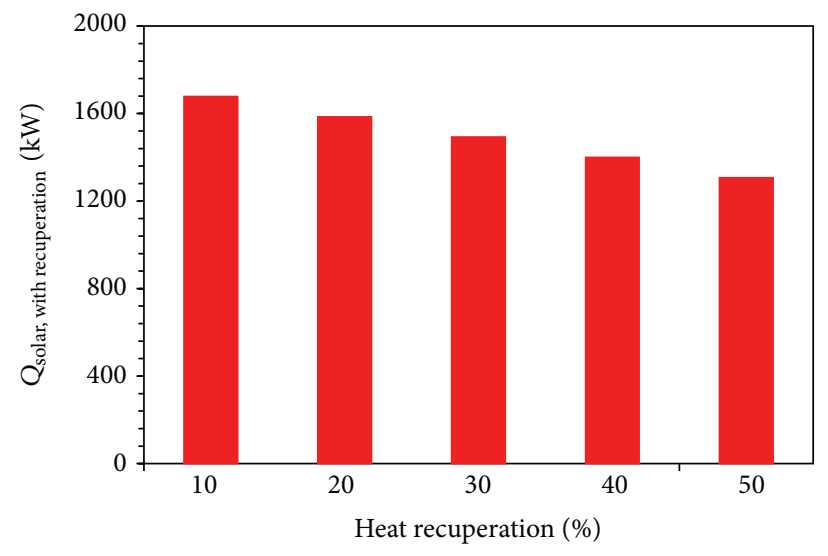

(b)

FIGURE 10: Effect of $\%$ heat recuperation on $Q_{\text {solar,with recuperation }}$ and $Q_{\text {recuperable }}\left(T_{H}=2280 \mathrm{~K}\right)$.

TABLE 1: $\operatorname{Irr}_{\text {reactor }}$ and $\operatorname{Irr}_{\text {quench }}$ as a function of $T_{H}$ for Tb-WS cycle.

\begin{tabular}{lcc}
\hline$T_{H}(\mathrm{~K})$ & $\operatorname{Irr}_{\text {reactor }}(\mathrm{kW} / \mathrm{K})$ & $\operatorname{Irr}_{\text {quench }}(\mathrm{kW} / \mathrm{K})$ \\
\hline 2780 & 2.3 & 1.6 \\
2700 & 1.9 & 1.6 \\
2520 & 1.2 & 1.5 \\
2280 & 0.6 & 1.5 \\
\hline
\end{tabular}

indicate $\eta_{\text {cycle }}$ of $20.3 \%$ and $\eta_{\text {solar-to-fuel }}$ of $24.5 \%$ at $T_{H}$ of $2780 \mathrm{~K}$. However, at lower $T_{H}(2280 \mathrm{~K})$, higher $\eta_{\text {cycle }}(26.8 \%)$ and $\eta_{\text {solar-to-fuel }}(32.3 \%)$ can be achieved. $\eta_{\text {solar-to-fuel }}$ of the TbWS cycle at $T_{H}$ of $2280 \mathrm{~K}$ is comparable to the efficiency values reported by previous investigators in case of $\mathrm{ZnO} / \mathrm{Zn}$ cycle (29\%), $\mathrm{SnO}_{2} / \mathrm{SnO}$ cycle $(29.8 \%), \mathrm{Fe}_{3} \mathrm{O}_{4} / \mathrm{FeO}$ cycle $(30 \%)$, and ceria cycle $(20.2 \%)$

$\eta_{\text {cycle }}$ and $\eta_{\text {solar-to-fuel }}$ of Tb-WS cycle can be increased further by reutilizing the heat released by the water splitting reactor and quench unit. The amount of heat that can be recuperated is calculated as

$$
Q_{\text {recuperable }}=Q_{\text {quench }}+Q_{\text {Sm oxidation }} \text {. }
$$

As the heat released by the water splitting reactor and quench unit is recycled to run the Tb-WS cycle, the amount of solar energy required will be decreased as

$$
\begin{aligned}
& Q_{\text {solar,with recuperation }} \\
& \quad=Q_{\text {solar }}-\left[(\% \text { recuperation }) Q_{\text {recuperable }}\right] .
\end{aligned}
$$

In case of $T_{H}$ of $2280 \mathrm{~K}$, Figure 10 shows that as the $\%$ heat recuperation increases, $Q_{\text {recuperable }}$ enhances whereas $Q_{\text {solar,with recuperation }}$ diminishes. At $10 \%$ heat recuperation, $Q_{\text {solar,with recuperation }}$ is equal to $1677.8 \mathrm{~kW}$, which can be decreased to $1306.8 \mathrm{~kW}$ due to the increase in the heat recuperation up to $50 \%$.
TABLE 2: $\eta_{\text {cycle }}$ and $\eta_{\text {solar-to-fuel }}$ of Tb-WS cycle.

\begin{tabular}{lcc}
\hline$T_{H}(\mathrm{~K})$ & $\eta_{\text {cycle }}(\%)$ & $\eta_{\text {solar-to-fuel }}(\%)$ \\
\hline Recuperation $=0 \%$ & & \\
2780 & 20.3 & 24.5 \\
2700 & 21.4 & 25.9 \\
2520 & 24.0 & 29.0 \\
2280 & 26.7 & 32.3 \\
Recuperation $=20 \%$ & & \\
2780 & 22.1 & 26.7 \\
2700 & 23.5 & 28.3 \\
2520 & 26.6 & 32.1 \\
2280 & 29.9 & 36.0 \\
Recuperation $=40 \%$ & & \\
2780 & 24.3 & 29.4 \\
2700 & 26.0 & 31.4 \\
2520 & 29.7 & 35.9 \\
2280 & 33.8 & 40.8 \\
Recuperation $=60 \%$ & & \\
2780 & 27.0 & 32.6 \\
2700 & 29.1 & 35.1 \\
2520 & 33.8 & 40.8 \\
2280 & 39.0 & 47.1 \\
\hline
\end{tabular}

After applying the heat recuperation, $\eta_{\text {cycle }}$ and $\eta_{\text {solar-to-fuel }}$ associated with the Tb-WS cycle can be calculated as

$$
\begin{aligned}
\eta_{\text {cycle }} & =\frac{W_{\text {FC-Ideal }}}{Q_{\text {solar,with recuperation }}} \\
\eta_{\text {solar-to-fuel }} & =\frac{\mathrm{HHV}_{\mathrm{H}_{2}}}{Q_{\text {solar,with recuperation }}} .
\end{aligned}
$$

Table 2 reports $\eta_{\text {cycle }}$ and $\eta_{\text {solar-to-fuel }}$ of Tb-WS cycle for different $T_{H}$ and by applying 10 to $50 \%$ heat recuperation. For the data listed, it can be seen that, due to the inclusion of heat recuperation, both $\eta_{\text {cycle }}$ and $\eta_{\text {solar-to-fuel }}$ of $\mathrm{Tb}$-WS cycle are significantly improved. For instance, by applying 
$20 \%$ heat recuperation at $T_{H}$ of $2280 \mathrm{~K}, \eta_{\text {cycle }}$ and $\eta_{\text {solar-to-fuel }}$ can be increased up to 23.5 and $28.4 \%$. Likewise, at heat recuperation of $60 \%$ and $T_{H}$ of $2280 \mathrm{~K}, \eta_{\text {cycle }}$ and $\eta_{\text {solar-to-fuel }}$ can get enhanced up to 39.0 and $47.1 \%$.

According to the previous studies, the heat recuperation is highly essential to achieve higher efficiency values in case of metal oxide based solar thermochemical cycles $[12,14,15$, $17,18,43,44]$. In the past, attempts were made to achieve the heat recuperation in a real-life solar reactor system. For instance, Diver et al. [45] developed a heat recovery system for iron oxide cycle by using a stack of counter-rotating rings with the reactive material along the perimeter of each ring. In this system, the reactive surfaces act as extended heat transfer surfaces to achieve heat recuperation. Similarly, in case of TbWS cycle, heat exchangers can be coupled with the quench unit and water splitting reactor to recover the latent and sensible heat rejected by these units. Suitable heat exchanger fluid needs to be selected and the heat rejected by quench unit (due to the cooling of the thermal reduction products) and water splitting reactor (due to the exothermic splitting of water) can be stored in this fluid. This fluid can be recirculated throughout the process configuration shown in Figure 5 and the captured heat can be reutilized to run the Tb-WS cycle.

The solar reactor thermodynamic modeling performed in this paper is also verified by performing an energy balance and by evaluating the maximum achievable efficiency from the total available work and from the total solar power input. The energy balance performed in case of Tb-WS cycle (for all $T_{H}$ ) confirms that

$$
\begin{aligned}
& W_{\text {FC-Ideal }}=Q_{\text {solar }} \\
& \quad-\left(Q_{\text {reradiation }}+Q_{\text {quench }}+Q_{\text {Sm oxidation }}+Q_{\text {FC-Ideal }}\right) .
\end{aligned}
$$

As an example, at $T_{H}$ of $2280 \mathrm{~K}$, (22) indicates $W_{\text {FC-Ideal }}$ of $473.9 \mathrm{~kW}$ which is equal to $W_{\text {FC-Ideal }}$ determined by (14). Furthermore, the maximum cycle efficiency is also calculated according to

$$
\begin{aligned}
& \eta_{\text {cycle,maximum }} \\
& =\frac{W_{\text {FC-Ideal }}+T_{L}\left(\operatorname{Irr}_{\text {reactor }}+\operatorname{Irr}_{\text {quench }}+\operatorname{Irr}_{\text {Sm oxidation }}\right)}{Q_{\text {solar }}} .
\end{aligned}
$$

For all $T_{H}$, it was observed that $\eta_{\text {cycle,maximum }}$ is equal to the Carnot heat engine operating between hot and cold temperature reservoirs:

$$
\eta_{\text {cycle,maximum }}=1-\frac{T_{L}}{T_{H}}=\eta_{\text {carnot }} .
$$

For instance, at $T_{H}$ of $2280 \mathrm{~K}$ and $T_{L}$ of $298 \mathrm{~K}, \eta_{\text {cycle,maximum }}$ is $86.9 \%$ which is equal to $\eta_{\text {carnot }}=86.9 \%$.

\section{Summary and Conclusions}

Solar reactor efficiency analysis of the Tb-WS cycle for the production of $\mathrm{H}_{2}$ via water splitting reaction was conducted by using HSC Chemistry software and databases. Simulation results indicate that the heat energy required for the

complete reduction of $\mathrm{TbO}_{2}$ into $\mathrm{Tb}$ and $\mathrm{O}_{2}$ can be reduced significantly from 2780 to $2280 \mathrm{~K}$ by decreasing the oxygen partial pressure in the inert flushing gas from $10^{-5}$ to $10^{-8}$ atm. According to the simulations, the water splitting reaction via $\mathrm{Tb}$ oxidation is feasible below $5400 \mathrm{~K}$.

Exergy analysis shows that $\eta_{\text {absorption }}$ of the Tb-WS solar reactor can be increased by a factor of 1.28 due to the decrease in $T_{H}$ from 2780 to $2280 \mathrm{~K}$. It was also observed that $Q_{\text {reactor-net }}$ and $Q_{\text {solar }}$ can be reduced by 43.8 and $562.7 \mathrm{~kW}$ with the lowering of $T_{H}$ from 2780 to $2280 \mathrm{~K}$. Similarly, due to the similar fall in $T_{H}$, the quenching and reradiation heat losses can be dropped by 7.7 and $65.7 \%$, respectively. The reason for the lower amounts of solar energy requirement and reduction in the heat loss via quenching and reradiation is due to the fact that $\eta_{\text {absorption }}$ of the Tb-WS solar reactor improves with the decrease in $T_{H} \cdot \eta_{\text {cycle }}$ of $23.5 \%$ and $\eta_{\text {solar-to-fuel }}$ of $28.4 \%$ of Tb-WS cycle at $T_{H}$ of $2280 \mathrm{~K}$ are observed to be comparable to the previously investigated MO cycles. Furthermore, $\eta_{\text {cycle }}$ and $\eta_{\text {solar-to-fuel }}$ can be further increased up to $39.0 \%$ and $47.1 \%$ by recuperating $60 \%$ of the heat rejected by the quench unit and water splitting reactor.

\section{Nomenclature}

C:

HHV:

I:

$\mathrm{MO}:$

$\dot{n}$ :

$Q_{\text {quench }}$ :

$Q_{\text {FC-Ideal }}$ :

$Q_{\mathrm{Tb} \text { oxidation }}$ :

$Q_{\mathrm{TbO}_{2} \text {-heating }}$ :

$Q_{\mathrm{TbO}_{2} \text {-reduction }}$ :

$Q_{\text {reactor-net }}$

$Q_{\text {reradiation: }}$

$Q_{\text {recuperable: }}$

$Q_{\text {solar }}$ :

$Q_{\text {solar,with recuperation }}$

$T_{H}$ :

$T_{L}$ :

$W_{\text {FC-Ideal }}$ :

$\eta_{\text {absorption }}$ :

$\eta_{\text {cycle }}$ :

$\eta_{\text {solar-to-fuel }}:$

$\Delta G_{\mathrm{WS}}$ :

$\Delta H_{\mathrm{WS}}$ :
Solar flux concentration ratio, suns Higher heating value Normal beam solar insolation, $\mathrm{W} / \mathrm{m}^{2}$ Metal oxide

Molar flow rate, $\mathrm{mol} / \mathrm{sec}$

Heat rejected to the surrounding from quench unit, $\mathrm{kW}$

Heat rejected to the surrounding from ideal fuel cell, $\mathrm{kW}$

Heat rejected to the surrounding from water splitting reactor, $\mathrm{kW}$ Energy required for heating of $\mathrm{TbO}_{2}$, $\mathrm{kW}$

Energy required for the thermal reduction of $\mathrm{TbO}_{2}, \mathrm{~kW}$

Net energy input required for the operation of Tb-WS cycle, $\mathrm{kW}$

Radiation heat loss from the solar reactor, $\mathrm{kW}$

Total amount of heat that can be recuperated, $\mathrm{kW}$

Solar energy input, kW

Solar power input after heat recuperation, $\mathrm{kW}$

Thermal reduction temperature, $\mathrm{K}$ Water splitting temperature, $\mathrm{K}$ Work output of an ideal fuel cell, kW Solar absorption efficiency Cycle efficiency

Solar-to-fuel energy conversion efficiency

Gibbs free energy change for water splitting reaction, $\mathrm{kJ} / \mathrm{mol}$ Enthalpy change for water splitting reaction, $\mathrm{kJ} / \mathrm{mol}$ 


$$
\begin{array}{ll}
\Delta S_{\mathrm{WS}}: & \begin{array}{l}
\text { Entropy change for water splitting } \\
\text { reaction, } \mathrm{J} / \mathrm{mol} \cdot \mathrm{K}
\end{array} \\
\sigma: & \begin{array}{l}
\text { Stefan-Boltzmann constant, } \\
5.670 \times 10^{-8}\left(\mathrm{~W} / \mathrm{m}^{2} \cdot \mathrm{K}^{4}\right)
\end{array} \\
\mathrm{Irr}_{\text {reactor }}: & \begin{array}{l}
\text { Rate of entropy produced across solar } \\
\text { reactor, } \mathrm{kW} / \mathrm{K}
\end{array} \\
\mathrm{Irr}_{\text {quench }}: & \begin{array}{l}
\text { Rate of entropy produced across } \\
\text { quench unit, } \mathrm{kW} / \mathrm{K}
\end{array} \\
\mathrm{Irr}_{\text {Sm oxidation }}: & \text { Rate of entropy produced across } \\
& \text { water splitting reactor, } \mathrm{kW} / \mathrm{K} .
\end{array}
$$

\section{Conflict of Interests}

The authors declare that there is no conflict of interests regarding the publication of this paper.

\section{Acknowledgment}

The authors gratefully acknowledge the financial support provided by the Qatar University Internal Grant (QUUGCENG-CHE-14/15-10).

\section{References}

[1] N. Z. Muradov, "How to produce hydrogen from fossil fuels without $\mathrm{CO}_{2}$ emission," International Journal of Hydrogen Energy, vol. 18, no. 3, pp. 211-215, 1993.

[2] N. Muradov, "Hydrogen via methane decomposition: an application for decarbonization of fossil fuels," International Journal of Hydrogen Energy, vol. 26, no. 11, pp. 1165-1175, 2001.

[3] M. S. Herdem, S. Farhad, I. Dincer, and F. Hamdullahpur, "Thermodynamic modeling and assessment of a combined coal gasification and alkaline water electrolysis system for hydrogen production," International Journal of Hydrogen Energy, vol. 39, no. 7, pp. 3061-3071, 2014.

[4] R. Tungal and R. V. Shende, "Hydrothermal liquefaction of pinewood (Pinus ponderosa) for $\mathrm{H}_{2}$, biocrude and bio-oil generation," Applied Energy, vol. 134, pp. 401-412, 2014.

[5] A. J. Byrd, S. Kumar, L. Kong, H. Ramsurn, and R. B. Gupta, "Hydrogen production from catalytic gasification of switchgrass biocrude in supercritical water," International Journal of Hydrogen Energy, vol. 36, no. 5, pp. 3426-3433, 2011.

[6] D. Vera, F. Jurado, K. D. Panopoulos, and P. Grammelis, "Modelling of biomass gasifier and microturbine for the olive oil industry," International Journal of Energy Research, vol. 36, no. 3, pp. 355-367, 2012.

[7] P. Parthasarathy and K. S. Narayanan, "Hydrogen production from steam gasification of biomass: influence of process parameters on hydrogen yield-a review," Renewable Energy, vol. 66, pp. 570-579, 2014.

[8] A. Ashok, A. Kumar, R. R. Bhosale, M. A. H. Saleh, and L. J. P. van den Broeke, "Cellulose assisted combustion synthesis of porous $\mathrm{Cu}-\mathrm{Ni}$ nanopowders," RSC Advances, vol. 5, no. 36, pp. 28703-28712, 2015.

[9] A. Cross, A. Kumar, E. E. Wolf, and A. S. Mukasyan, "Combustion synthesis of a nickel supported catalyst: effect of metal distribution on the activity during ethanol decomposition," Industrial \& Engineering Chemistry Research, vol. 51, no. 37, pp. 12004-12008, 2012.
[10] A. Kumar, A. S. Mukasyan, and E. E. Wolf, "Impregnated layer combustion synthesis method for preparation of multicomponent catalysts for the production of hydrogen from oxidative reforming of methanol," Applied Catalysis A: General, vol. 372, no. 2, pp. 175-183, 2010.

[11] A. Kumar, A. Cross, K. Manukyan et al., "Combustion synthesis of copper-nickel catalysts for hydrogen production from ethanol," Chemical Engineering Journal, vol. 278, pp. 46-54, 2015.

[12] A. Steinfeld, "Solar hydrogen production via a two-step watersplitting thermochemical cycle based on $\mathrm{Zn} / \mathrm{ZnO}$ redox reactions," International Journal of Hydrogen Energy, vol. 27, no. 6, pp. 611-619, 2002.

[13] S. Abanades, P. Charvin, and G. Flamant, "Design and simulation of a solar chemical reactor for the thermal reduction of metal oxides: case study of zinc oxide dissociation," Chemical Engineering Science, vol. 62, no. 22, pp. 6323-6333, 2007.

[14] J. R. Scheffe and A. Steinfeld, "Oxygen exchange materials for solar thermochemical splitting of $\mathrm{H}_{2} \mathrm{O}$ and $\mathrm{CO}_{2}$ : a review," Materials Today, vol. 17, no. 7, pp. 341-348, 2014.

[15] D. Dardor, R. R. Bhosale, S. Gharbia, A. Kumar, and F. Al Momani, "Solar carbon production via thermochemical $\mathrm{ZnO} / \mathrm{Zn}$ carbon dioxide splitting cycle," Journal of Emerging Trends in Engineering and Applied Sciences, vol. 6, pp. 129-135, 2015.

[16] S. Abanades and H. I. Villafan-Vidales, " $\mathrm{CO}_{2}$ and $\mathrm{H}_{2} \mathrm{O}$ conversion to solar fuels via two-step solar thermochemical looping using iron oxide redox pair," Chemical Engineering Journal, vol. 175, no. 1, pp. 368-375, 2011.

[17] M. E. Gálvez, P. G. Loutzenhiser, I. Hischier, and A. Steinfeld, " $\mathrm{CO}_{2}$ splitting via two-step solar thermochemical cycles with $\mathrm{Zn} / \mathrm{ZnO}$ and $\mathrm{FeO} / \mathrm{Fe}_{3} \mathrm{O}_{4}$ redox reactions: thermodynamic analysis," Energy \& Fuels, vol. 22, no. 5, pp. 3544-3550, 2008.

[18] J. E. Miller, M. D. Allendorf, R. B. Diver, L. R. Evans, N. P. Siegel, and J. N. Stuecker, "Metal oxide composites and structures for ultra-high temperature solar thermochemical cycles," Journal of Materials Science, vol. 43, no. 14, pp. 4714-4728, 2008.

[19] M. Roeb, J.-P. Säck, P. Rietbrock et al., "Test operation of a $100 \mathrm{~kW}$ pilot plant for solar hydrogen production from water on a solar tower," Solar Energy, vol. 85, no. 4, pp. 634-644, 2011.

[20] R. R. Bhosale, A. Kumar, L. J. P. van den Broeke et al., "Solar hydrogen production via thermochemical iron oxide-iron sulfate water splitting cycle," International Journal of Hydrogen Energy, vol. 40, no. 4, pp. 1639-1650, 2015.

[21] S. Abanades, " $\mathrm{CO}_{2}$ and $\mathrm{H}_{2} \mathrm{O}$ reduction by solar thermochemical looping using $\mathrm{SnO}_{2} / \mathrm{SnO}$ redox reactions: thermogravimetric analysis," International Journal of Hydrogen Energy, vol. 37, no. 10, pp. 8223-8231, 2012.

[22] P. Charvin, S. Abanades, F. Lemont, and G. Flamant, "Experimental study of $\mathrm{SnO}_{2} / \mathrm{SnO} / \mathrm{Sn}$ thermochemical systems for solar production of hydrogen," AIChE Journal, vol. 54, no. 10, pp. 2759-2767, 2008.

[23] D. Dardor, R. Bhosale, S. Gharbia, A. AlNouss, A. Kumar, and F. AlMomani, "Solar thermochemical conversion of $\mathrm{CO}_{2}$ into C via $\mathrm{SnO}_{2} / \mathrm{SnO}$ redox cycle: a thermodynamic study," International Journal of Engineering Research \& Applications, vol. 5, no. 4, pp. 134-140, 2015.

[24] C. C. Agrafiotis, C. Pagkoura, A. Zygogianni, G. Karagiannakis, M. Kostoglou, and A. G. Konstandopoulos, "Hydrogen production via solar-aided water splitting thermochemical cycles: combustion synthesis and preliminary evaluation of spinel 
redox-pair materials," International Journal of Hydrogen Energy, vol. 37, no. 11, pp. 8964-8980, 2012.

[25] R. R. Bhosale, R. Shende, and J. Puszynski, " $\mathrm{H}_{2}$ Generation from thermochemical water-splitting using sol-gel synthesized $\mathrm{Zn} / \mathrm{Sn} / \mathrm{Mn}$-doped Ni-ferrite," International Review of Chemical Engineering, vol. 2, no. 7, pp. 852-862, 2012.

[26] R. R. Bhosale, R. V. Shende, and J. A. Puszynski, "Thermochemical water-splitting for $\mathrm{H}_{2}$ generation using sol-gel derived Mn-ferrite in a packed bed reactor," International Journal of Hydrogen Energy, vol. 37, no. 3, pp. 2924-2934, 2012.

[27] R. Bhosale, R. Khadka, J. Puszynski, and R. Shende, " $\mathrm{H}_{2}$ generation from two-step thermochemical water-splitting reaction using sol-gel derived $\mathrm{Sn}_{\mathrm{x}} \mathrm{Fe}_{\mathrm{y}} \mathrm{O}_{\mathrm{z}}$," Journal of Renewable and Sustainable Energy, vol. 3, no. 6, Article ID 063104, 2011.

[28] R. Bhosale, R. Shende, and J. Puszynski, " $\mathrm{H}_{2}$ generation from thermochemical water splitting using sol-gel derived $\mathrm{Ni}$ ferrite," Journal of Energy and Power Engineering, vol. 4, pp. 2738, 2010.

[29] F. Fresno, T. Yoshida, N. Gokon, R. Fernández-Saavedra, and T. Kodama, "Comparative study of the activity of nickel ferrites for solar hydrogen production by two-step thermochemical cycles," International Journal of Hydrogen Energy, vol. 35, no. 16, pp. 8503-8510, 2010.

[30] M. Neises, M. Roeb, M. Schmücker, C. Sattler, and R. PitzPaal, "Kinetic investigations of the hydrogen production step of a thermochemical cycle using mixed iron oxides coated on ceramic substrates," International Journal of Energy Research, vol. 34, no. 8, pp. 651-661, 2010.

[31] S. Abanades and G. Flamant, "Thermochemical hydrogen production from a two-step solar-driven water-splitting cycle based on cerium oxides," Solar Energy, vol. 80, no. 12, pp. 1611$1623,2006$.

[32] P. Furler, J. R. Scheffe, and A. Steinfeld, "Syngas production by simultaneous splitting of $\mathrm{H}_{2} \mathrm{O}$ and $\mathrm{CO}_{2}$ via ceria redox reactions in a high-temperature solar reactor," Energy \& Environmental Science, vol. 5, no. 3, pp. 6098-6103, 2012.

[33] P. Furler, J. Scheffe, M. Gorbar, L. Moes, U. Vogt, and A. Steinfeld, "Solar thermochemical $\mathrm{CO}_{2}$ splitting utilizing a reticulated porous ceria redox system," Energy \& Fuels, vol. 26, no. 11, pp. 7051-7059, 2012.

[34] P. T. Krenzke and J. H. Davidson, "On the efficiency of solar $\mathrm{H}_{2}$ and $\mathrm{CO}$ production via the thermochemical cerium oxide redox cycle: the option of inert-swept reduction," Energy \& Fuels, vol. 29, no. 2, pp. 1045-1054, 2015.

[35] A. Le Gal and S. Abanades, "Dopant incorporation in ceria for enhanced water-splitting activity during solar thermochemical hydrogen generation," The Journal of Physical Chemistry C, vol. 116, no. 25, pp. 13516-13523, 2012.

[36] J. R. Scheffe, R. Jacot, G. R. Patzke, and A. Steinfeld, "Synthesis, characterization, and thermochemical redox performance of $\mathrm{Hf}^{4+}, \mathrm{Zr}^{4+}$, and $\mathrm{Sc}^{3+}$ doped ceria for splitting $\mathrm{CO}_{2}$," The Journal of Physical Chemistry C, vol. 117, no. 46, pp. 24104-24110, 2013.

[37] A. Demont and S. Abanades, "High redox activity of Srsubstituted lanthanum manganite perovskites for two-step thermochemical dissociation of $\mathrm{CO}_{2}$," RSC Advances, vol. 4, no. 97, pp. 54885-54891, 2014.

[38] A. Evdou, V. Zaspalis, and L. Nalbandian, " $\mathrm{La}_{1-x} \mathrm{Sr}_{x} \mathrm{FeO}_{3-\delta}$ perovskites as redox materials for application in a membrane reactor for simultaneous production of pure hydrogen and synthesis gas," Fuel, vol. 89, no. 6, pp. 1265-1273, 2010.

[39] M. E. Gálvez, R. Jacot, J. Scheffe, T. Cooper, G. Patzke, and A. Steinfeld, "Physico-chemical changes in $\mathrm{Ca}, \mathrm{Sr}$ and Al-doped
La-Mn-O perovskites upon thermochemical splitting of $\mathrm{CO}_{2}$ via redox cycling," Physical Chemistry Chemical Physics, vol. 17, no. 9, pp. 6629-6634, 2015.

[40] A. H. McDaniel, E. C. Miller, D. Arifin et al., "Sr-and Mn-doped $\mathrm{LaAlO}_{3-\delta}$ for solar thermochemical $\mathrm{H}_{2}$ and $\mathrm{CO}$ production," Energy \& Environmental Science, vol. 6, pp. 2424-2428, 2013.

[41] J. R. Scheffe, D. Weibel, and A. Steinfeld, "Lanthanumstrontium-manganese perovskites as redox materials for solar thermochemical splitting of $\mathrm{H}_{2} \mathrm{O}$ and $\mathrm{CO}_{2}$," Energy \& Fuels, vol. 27, no. 8, pp. 4250-4257, 2013.

[42] P. Patnaik, Handbook of Inorganic Chemical Compounds, McGraw-Hill, 2003.

[43] J. R. Scheffe and A. Steinfeld, "Thermodynamic analysis of cerium-based oxides for solar thermochemical fuel production," Energy \& Fuels, vol. 26, no. 3, pp. 1928-1936, 2012.

[44] R. Bader, L. J. Venstrom, J. H. Davidson, and W. Lipiński, "Thermodynamic analysis of isothermal redox cycling of ceria for solar fuel production," Energy \& Fuels, vol. 27, no. 9, pp. 5533-5544, 2013.

[45] R. B. Diver, J. E. Miller, M. D. Allendorf, N. P. Siegel, and R. E. Hogan, "Solar thermochemical water-splitting ferrite-cycle heat engines," Journal of Solar Energy Engineering, vol. 130, no. 4, Article ID 041001, 2008. 

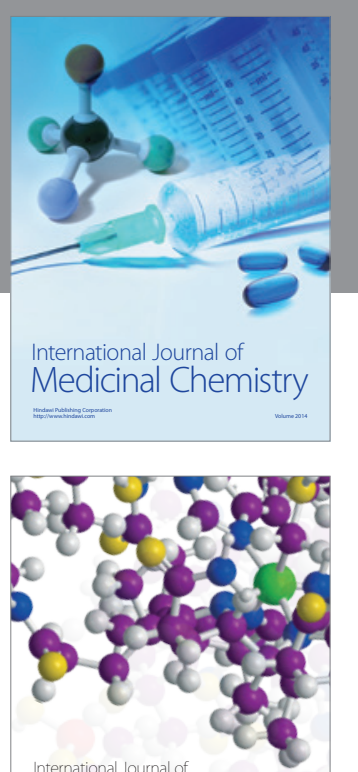

Carbohydrate Chemistry

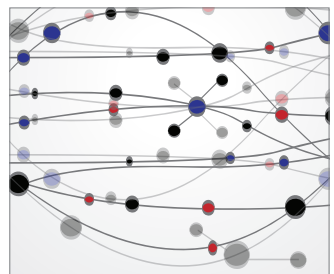

The Scientific World Journal
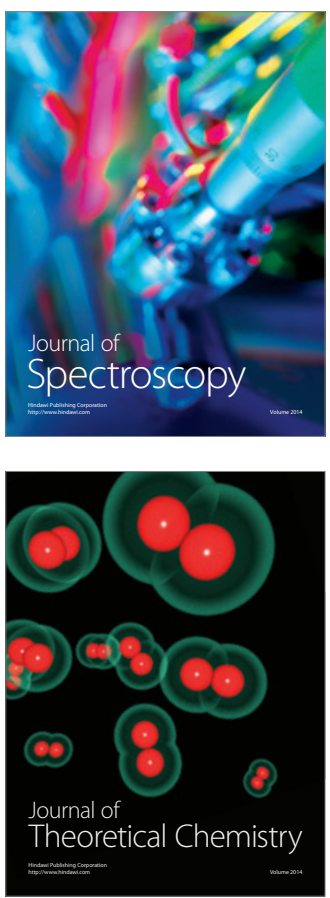
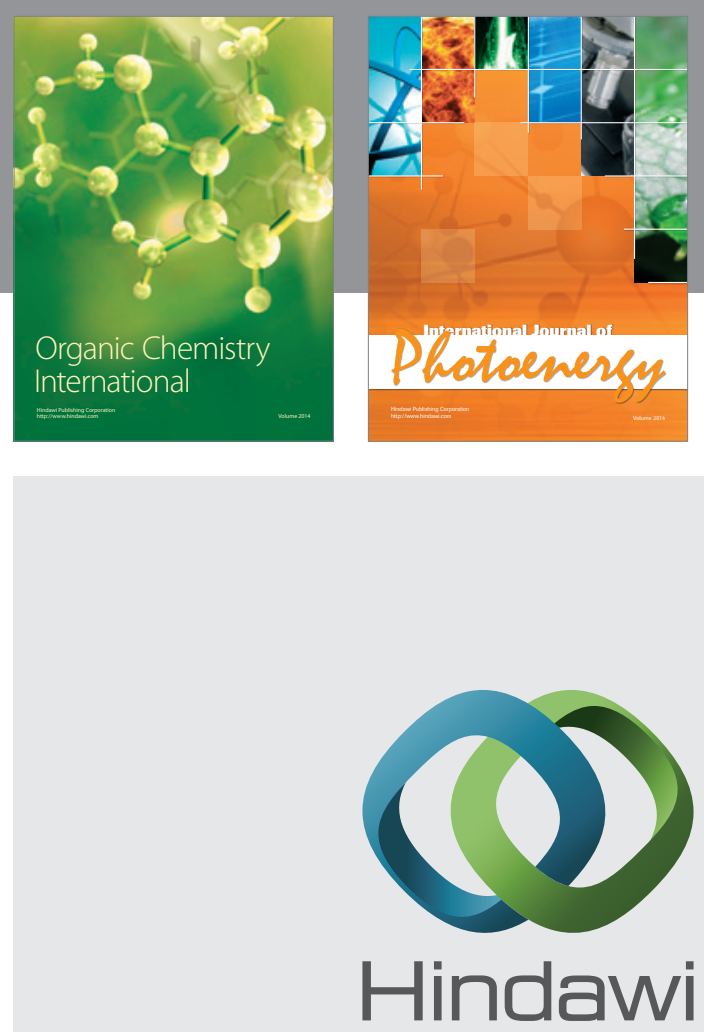

Submit your manuscripts at

http://www.hindawi.com

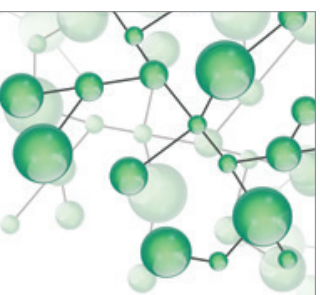

International Journal of

Inorganic Chemistry

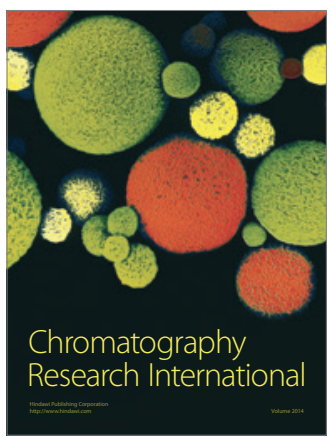

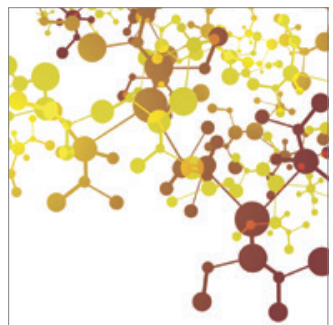

Applied Chemistry
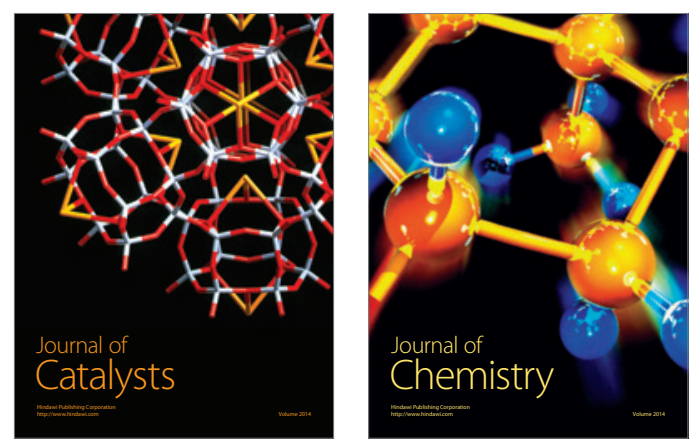
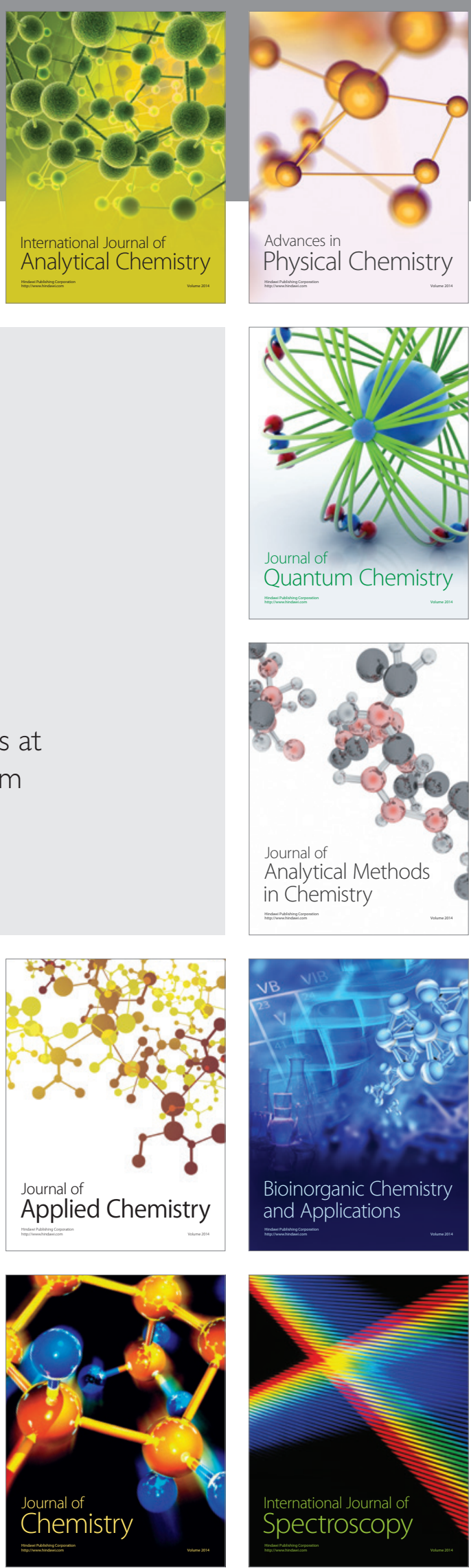